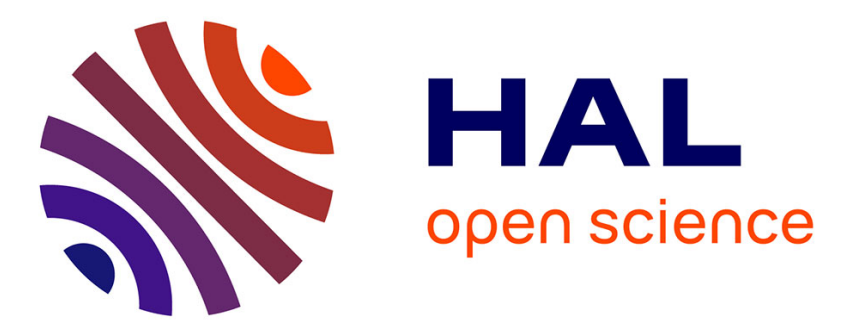

\title{
"Structures Ia pour deux pianos" by Boulez: towards creative analysis using OpenMusic and Rubato
}

\author{
Yun-Kang Ahn, Carlos Agon, Moreno Andreatta
}

\section{To cite this version:}

Yun-Kang Ahn, Carlos Agon, Moreno Andreatta. "Structures Ia pour deux pianos" by Boulez: towards creative analysis using OpenMusic and Rubato. Mathematics and Computation in Music, May 2007, Berlin, Germany. pp.234-238, 10.1007/978-3-642-04579-0_41 . hal-01161384

\section{HAL Id: hal-01161384 \\ https://hal.science/hal-01161384}

Submitted on 8 Jun 2015

HAL is a multi-disciplinary open access archive for the deposit and dissemination of scientific research documents, whether they are published or not. The documents may come from teaching and research institutions in France or abroad, or from public or private research centers.
L'archive ouverte pluridisciplinaire HAL, est destinée au dépôt et à la diffusion de documents scientifiques de niveau recherche, publiés ou non, émanant des établissements d'enseignement et de recherche français ou étrangers, des laboratoires publics ou privés. 


\title{
"Structures Ia pour deux pianos" by Boulez : towards creative analysis using OpenMusic and Rubato
}

\author{
Yun-Kang Ahn, Carlos Agon, and Moreno Andreatta \\ IRCAM, 1 place Igor Stravinsky, 75004 Paris, France, \\ \{yun-kang.ahn, agonc, moreno.andreatta\}@ircam.fr
}

\begin{abstract}
Pierre Boulez introduced the concept of "creative analysis" [5] in the late 80s: according to him, analysis has to aim at producing new pieces. Marcel Mesnage and André Riotte followed this way with works on computer-aided analysis and composition [14]. This study will focus on Ligeti's analysis of "Structures pour deux pianos Ia" (first book in 1951-1952) by Boulez, where the compositionnal process is described in detail and set a model. In "Structures", Boulez uses a series of 12 pitches borrowed from Messiaen's "Mode de valeurs et d'intensité", but also a series of 12 durations (borrowed from the same source), 12 attacks, and 12 dynamics. Following Boulez's conception, our task is to start from this compositional model to then consider how it could be used to produce an other piece.

First our work will start with the software OpenMusic, developed at the IRCAM, and built on functional paradigm. This graphical environment can be exploited to imitate the model used in "Structures", stressing on the functional point of view.

Then a parallel approach will deal with Rubato, an universal music software environment which has been developed at the University of Zurich. The categorical point of view theorized by Guerino Mazzola is the application keystone and is related to OpenMusic as functional languages and category theory are strongly linked. Rubato would bring an other abstraction level and therefore new possibilities that have to be developed.
\end{abstract}

\section{Introduction}

Musicology traditionnally distinguishes analysis and composition. Indeed these represent two different disciplines although they can be completely separated. Boulez aims at reuniting those 2 directions into what he calls "creative analysis" [6] [5]. Thus a musical work have to be considered as containing in its "potentiality", i.e. its possibility to open perspectives to new compositions.

Evolution of the link between mathematics and music [3] combined with development of music through computer science, has been leading composers and analysts to change their habits and to interest in music formalisation. 
We start introducing the compositional process used by Pierre Boulez before presenting the implementation of the model in OpenMusic. Afterwards we will deal with the perspectives of the implementation in Rubato that would guide the development of this project.

\section{Compositional process in "Structure Ia"}

\subsection{Analysis of constructional and serial principles: Decision and Automatism}

We mainly use for this work the famous analysis made by Ligeti on this piece [13] (see also [9], [10]). This describes the part of decision and automatism existing in the piece, automatism due to the serial technique.

Boulez aims at extending serial technique in his "Structures" (for details on his musical technique, see [7] and [8]). Therefore he chooses a twelve-tone series, that he arranges to form the same series as Division 1 of the note-succession from Messsiaen's "Mode de valeurs et d'intensités" in homage to his teacher (Fig. 1).

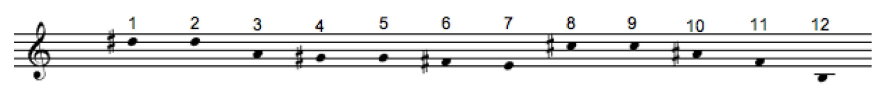

Fig. 1. The original series

Then Boulez considers two $12 * 12$ matrices : one matrix fostered by the 12 transpositions of the original series and a second one with the 12 transpositions of the inverted (by the first note) original series (Fig. 2). Therefore he picks paths in those matrices in order to organise serial threads defined by 12 pitches, durations, intensities, and dynamics. Boulez goes further than usual serialist composers as he applies this technique to durations, intensities and dynamics creating serial "threads" defined by 12 pitches, durations, intensities, and dynamics.

\subsection{How to create from an analysis}

This analysis of the compositional process leads us to ponder on the possibilities in order to compose. Ligeti doesn't forget to cope with this problem as he subrays the balance between automatism and decision, i.e. what concerns the composer's choice or not.

From this model we can undertake a kind of metacomposition with two softwares proposing different approaches, OpenMusic and Rubato. Guerino realised a piano sonata from an analysis made on the "Hammerklavier" sonata written by Beethoven [15]. 


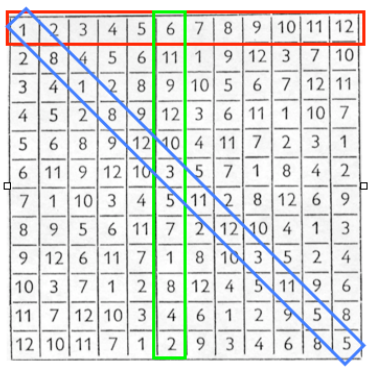

Fig. 2. One matrix and some paths used for the composition

\section{An implementation in OpenMusic : a visual and functional environment}

\subsection{Patches and circularity}

OpenMusic offers a Human-machine interface originally reserved to composition. Yet, as we will see it could be used in the context of musical analysis in order to compose [2]. Indeed there are few accessible softwares for theorists who are not necessarily used to using computers.

The basic unit of programming in OpenMusic is a patch. Generally speaking, a patch can consist of functions linked up to create a flowchart representing a task. The figure 3 shows the patch allowing the creation, from the original series given in input, of the two sections of the piece. Based on a functional paradigm (LISP/CLOS), OpenMusic takes advantage of recursivity as a patch can be built from other patches.

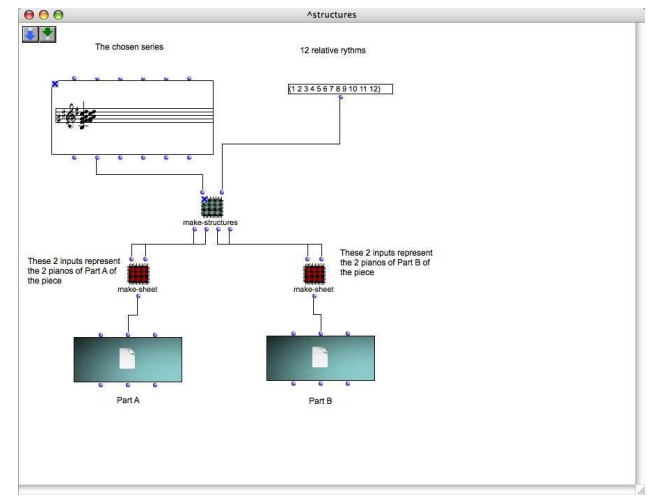

Fig. 3. The patch in OpenMusic reproducing the compositional process of "Structures Ia" 


\subsection{Composing following the model with the benefit of a graphical composition environment}

Given a twelve-note series, the patch applies the same process that Boulez defined. The patch produces a score where bundles defined by Boulez are displayed in tracks (Fig. 4). Each track can be then modified directly.

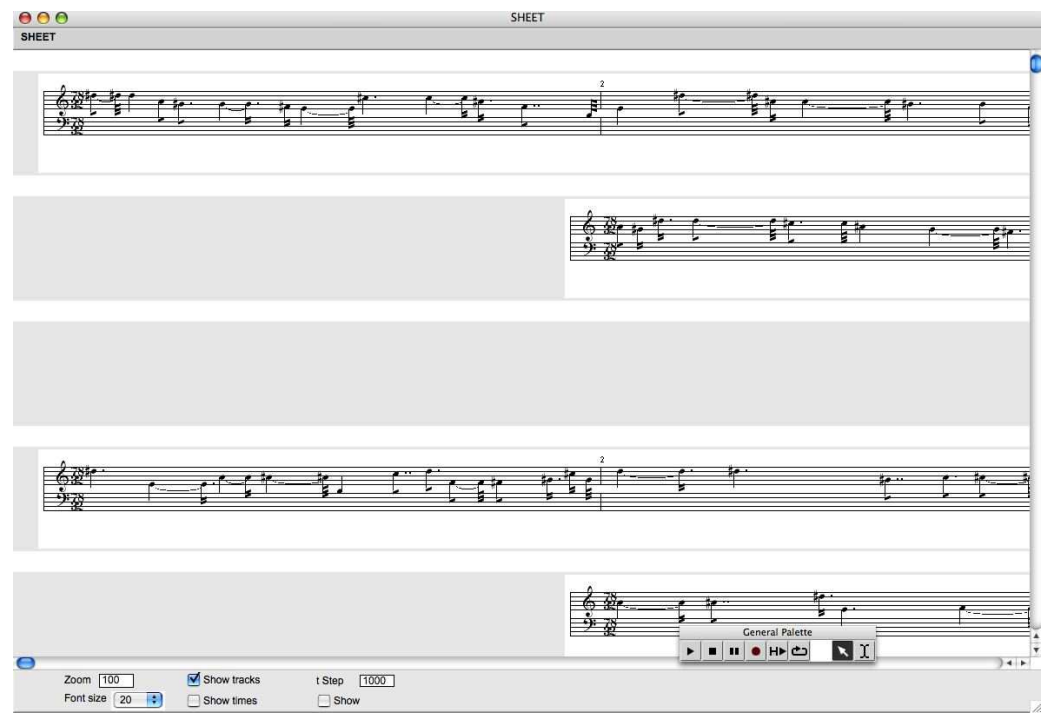

Fig. 4. The produced score in OpenMusic

Furthermore, according to Ligeti's analysis, registers (i.e. which octave do we select for the related pitch-set) are an important parameter to modify on the composition. We choose not to control dynamics as it remains difficult to set up in OpenMusic.

This emphasizes the distinction between automatism (the procedures contained in the patch) and decision (the allowed modifications on the result). Thus the user is able to create "errors" like Boulez did in his piece (according to Ligeti!).

\section{Rubato : A higher level of abstraction with a categorical view}

\subsection{Different perspectives brought by Rubato}

Rubato is based on a music theory introduced by Mazzola [16] and based on category theory (and especially on theory of topos), a branch of mathematics 
pointing out transformations rather than objects (this concept exists in musical analysis with transformational analysis developed by David Lewin [12]). Figure ?? displays the Rubato environment.

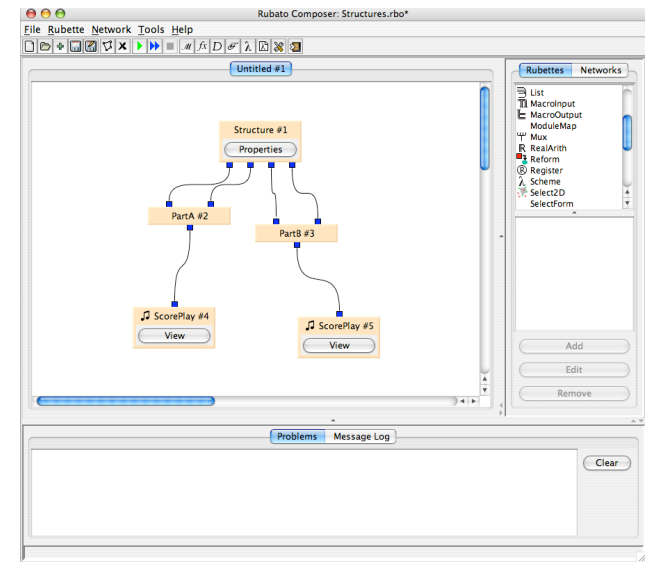

Fig. 5. The Rubato environment and an example of network

\subsection{Possibilities brought by Rubato}

This software involves higher abstraction as, for instance, it deals with generalized musical objects. Indeed objects like "melody" are defined, allowing new perspectives. So this background fits the combinatory point of view of the compositional process of Boulez, letting open fields to work on to develop a kind of metacomposition able to foster different pieces.

\subsection{Scheme of the construction}

The introduced theory allows us to speak of generalized points in space (i.e. addressed points instead of traditional points known from standard mathematical approaches). It means that we rather interest in morphisms (here module morphisms) than in objects.

The key concept is to rely on the module $\mathbb{Z}^{11}$ which is strongly related to the structure of the piece, with a twelve-tone qualities series and the $12 * 12$ matrices. Then the idea is to associate the 12 basis vectors of $\mathbb{Z}^{11}$ to each note (i.e. create a module morphism) (Fig. 6), and generalize this process associating them to each row of the matrices. Then permutations of basis vectors will allow to generate the piece. The result is displayed in figure 7 . 


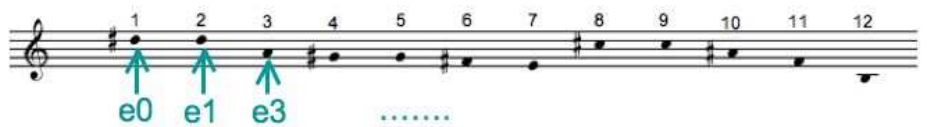

Fig. 6. Association of the 12 basis vectors of $\mathbb{Z}^{11}$ with 12 notes

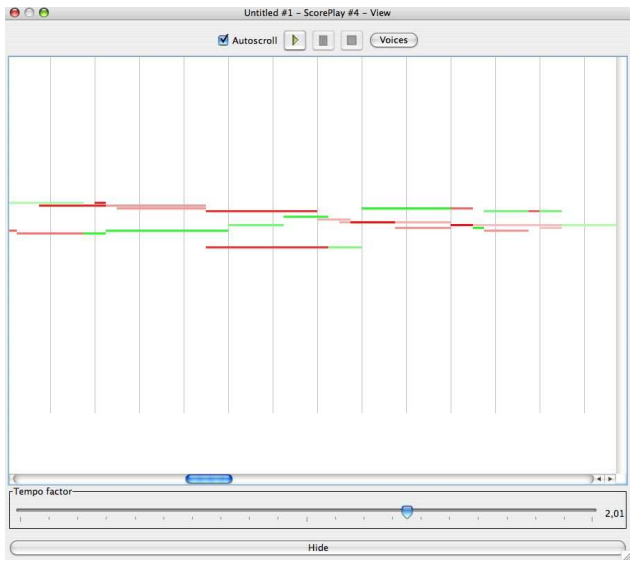

Fig. 7. The Rubato "score" of Structure Ia

\section{Conclusion}

OpenMusic and Rubato offers tools to plan compositional models and consequently allows composers to modify their vision and enlarge their possibilities. The models generally brought by analyses are subject to modifications that can generate other compositions after. From that on, this approach may be first generalized to other parameters (like instruments, etc.). Furthermore, the process used by Boulez may be thought in terms of permutations (and group of permutations) which could lead to new directions. 


\section{Bibliography}

[1] Agon, C.: OpenMusic : Un langage visuel pour la composition musicale assistée par ordinateur, PhD thesis, Paris VIII. (1998)

[2] Agon, C., Andreatta M., Assayag G., Schaub S. "Formal Aspects of Iannis Xenakis' "Symbolic Music": A Computer-Aided Exploration of Compositional Processes", Journal of New Music Research, vol. 33, no. 2, June. (2004)

[3] Andreatta, M.: Méthodes algébriques dans la musique et musicologie du $X X^{e}$ siècle: aspects théoriques, analytiques et compositionnels, PhD Thesis, EHESS/Ircam., pp 98-108. (2003)

[4] Babbitt, M.: The function of Set Structure in the Twelve-Tone System, PhD, Princeton University. (1946/1992)

[5] Boissière, A.: Geste, interprétation, invention selon Pierre Boulez, Revue DEMéter, décembre, Univ. Lille-3. (2002)

[6] Boulez, P.: Jalons (dix ans d'enseignement au Collège de France), Bourgeois, Paris. (1989)

[7] Boulez, P. : L'Ecriture du geste, Bourgeois, Paris. (2002)

[8] Boulez, P.: Penser la musique aujourd'hui, Ed. GONTHIER,Paris. (1963)

[9] Eimert, H.: "The composer Freedom and Choice", Die Reihe III, Universal Edition London and Theodore Presser Company. (1959)

[10] Feldman, M. and al.: "4 Musicians at Work." Trans/formation 1, no. 3, 168-172. (1952)

[11] Forte, A.: The Structure of Atonal Music, New Haven, Yale University Press. (1973)

[12] Lewin, D.: Generalized Musical Intervals and Transformations, New Haven, Yale University Press. (1982)

[13] Ligeti, G..: Pierre Boulez - Decision and Automatism in Structure IA, Die Reihe no. 4, pp. 36-62. (1975)

[14] Mesnage, M., Riotte A. "Modélisation informatique de partitions, analyse et composition assistées", Cahiers de l'Ircam no. 3, Paris, France. (1993)

[15] Mazzola, G.: L'essence du bleu, Acanthus, Rütenen. (2002)

[16] Mazzola, G.: The Topos of Music, Birkhäuser Verlag, Basel. (2003)

[17] Mesnage, M: "Techniques de segmentation automatique en analyse musicale", Musurgia. (1994) 